\title{
Comparative Assessment of Trace Metal Concentrations and Their Eco-Risk Analysis in Soils of the Vicinity of Roundhill Landfill, Southern Africa
}

\author{
Nyika Joan*† Onyari Ednah*, Megersa Olumana Dinka** and Shivani Bhardwaj Mishra*** \\ *University of South Africa, Department of Civil and Chemical Engineering, University of South Africa [Florida Science \\ Campus], Cnr Christian de Wet Road and Pioneer Avenue, Johannesburg, South Africa \\ **University of Johannesburg, Department of Civil Engineering Science, University of Johannesburg, APK Campus \\ 2006, Johannesburg, South Africa \\ ***University of South Africa, Nanotechnology and Water Sustainability Unit, University of South Africa \\ [Florida Science Campus], Cnr Christian de Wet Road and Pioneer Avenue, Johannesburg, South Africa \\ $\dagger$ Corresponding author: Nyika Joan; joashmada2011@gmail.com
}

Nat. Env. \& Poll. Tech

Website: www.neptjournal.com

Received: 08-07-2019

Accepted: 19-09-2019

Key Words:

Contaminants;

Ecological risk;

Landfill; Soil;

Trace metals

\begin{abstract}
Soil is a vital media in transmitting contaminants in the environment. Contamination of soils by trace metals has received much attention due to their associated toxicity, persistence, bioaccumulation and non-biodegradability that is harmful to the ecology. This study assayed the concentrations of trace metals in topsoils of the vicinity of Roundhill landfill using inductively coupled plasma-mass spectrometry (ICP-MS) and X-ray fluorescence (XRF), compared the detection capabilities of the two techniques and determined ecological risks of the contaminants using geographical information system. Soils were collected from nine sampling sites around Roundhill landfill in the Eastern Cape and analysed for five trace metals using the two techniques. Mean concentrations of $\mathrm{Cr}, \mathrm{Cu}, \mathrm{Ni}$ and $\mathrm{Zn}$ determined by ICP-MS and XRF were normally distributed $(p<0.05)$ from the parametric test while no significant differences between the two datasets were established from the non-parametric test. Under-estimated elemental concentrations determined by XRF were attributed to its high detection limits, matric effects, inter-elemental peak interferences and low sensitivity of the equipment. Correlation values of $\mathrm{Cr}, \mathrm{Cu}$ and $\mathrm{Ni}$ showed a high degree of linearity compared to $\mathrm{Pb}$. Evaluated eco-risk indices revealed low to extremely high ecological risks, posed by assessed trace elements in soils. Cr had the highest potency. Assayed trace metals were ecologically harmful to soils and their origin was linked to landfill leachate pollution.
\end{abstract}

\section{INTRODUCTION}

Soils provide many ecosystem services including vegetation support and modulating the flow of fugitive emissions, heat, nutrients and water (Wang et al. 2012). Besides, they adsorb and attenuate pollutants including trace metal elements. Consequently, trace metal pollution in soils is a growing environmental issue due to their non-biodegradability, bioaccumulation, persistence and toxicity (Zhu et al. 2018). Their entry in the food chain causes harm to organisms, including humans. The sources of these trace elements are either geogenic or anthropogenic-based. In the former, sources include pedogenesis and weathering activities on rocks while in the latter, use of agrochemicals, commercial fertilisers and unscientific disposal of waste, are the main pollution causes (Shokr et al. 2016). The distribution of trace metals in soils is dynamic and influenced by climate, soil parent material and its mobility. The rapid generation of the trace metals due to increased industrialisation and urbanisation activities worldwide and their capacity to become bioavailable and diffuse in other environments once disposed of explains the need to accurately quantify them (Wang et al. 2012, Shokr et al. 2016).

Different analytical techniques in in-situ and at ex-situ conditions have been developed to identify and quantify such pollutants in soils. Most of these assay methods are based on spectroscopy techniques and include X-ray fluorescence (XRF), atomic absorption spectrometry (AAS), inductively coupled plasma (ICP)- atomic emission spectrometry (AES) and ICP- mass spectrometry (ICP-MS) (Towett et al. 2013). ICP-MS/AES is common assay method based on aqua regia digestion to breakdown resistive metals and silicates in soils and have acceptable recovery and sensitivity. However, preconditions of sample pre-treatment before analysis that use concentrated acids are considered harsh and induce complex 
matrix effects that compromise accurate analysis of trace elements (McComb et al. 2014). Therefore, XRF analysis that is multi-elemental and non-destructive is a growing alternative to aqua-regia-based methods. XRF is dependent on wavelength-dispersive electro-technology, sensitive detectors and sample excitation to assay trace elements in soils and can be carried out intrusively or in-situ (Kilbride et al. 2006). Comparisons of aqua-regia digestion methods and XRF in trace element analysis in existent studies reported close linearity in some studies (Marcos et al. 2011, Towett et al. 2013, Poto et al. 2015) while in others, there were deviations in their sensitivity and detection limits (Kilbride et al. 2006, Radu \& Diamond 2009, McComb et al. 2014).

Using these techniques, trace elements can be quantified and their associated ecological risks measured using indices. Eco-risk indices reveal possible contamination in soils and the potency of specific metals to inflict environmental harm (Zhu et al. 2018). Most of the indices are derived from Hakanson's (1980) principle and are practical and quick tools to classify areas based on environmental pollution according to Wang et al. (2012). The distribution of ecorisk can be spatially represented if geographic information systems (GIS) are incorporated. According to Poggio \& Vrscaj (2009), GIS tools assess interactions between released trace elements and calculated eco-risk indices with recipient environs based on processes governing contaminant distribution and spatial information on sources. These interactions are interpolations over a georeferenced space and provide a basis for environmental assessment (Wang et al. 2012). In this way, ecological risk indices are diagnostic tools that show pollution pathways. The objectives of this study were to 1) determine contaminant concentrations of topsoils in the Roundhill landfill vicinity using ICP-MS and XRF, 2) compare the detection capabilities of the two techniques and 3) determine ecological risks of the contaminants using GIS.

\section{MATERIALS AND METHODS}

\section{Study Area and Sampling}

Roundhill landfill is located in Buffalo city municipality of Eastern Cape, South Africa and is situated at latitude $32^{\circ} 53^{\prime} 13.66^{\prime} \mathrm{S}$ and longitude $27^{\circ} 37^{\prime} 26.20^{\prime} \mathrm{E}$ (Fig. 1). The facility was commissioned in 2006 and was previously a natural grassland (Dookhi et al. 2015). It receives more than 500 tonnes of general wastes from domestic, healthcare, businesses and building sectors of the vicinity daily. The landfill has a geomembrane liner and a leachate collection system whose effectiveness has been overwhelmed by increased waste disposal at the facility. Consequenlty, waste is inadequately lined and covered while leachate runs off to surroundings posing as a pollution threat (Jewaskiewitz \& Dookhi 2017). The climate of the area borders the Mediterranean and humid subtropical climate characterised by an average annual temperature of $21^{\circ} \mathrm{C}$, rainfall ranging between $400-100 \mathrm{~mm} /$ year and evaporation of $160-170 \mathrm{~mm} / \mathrm{month}$. It has clayey soils, low organic matter and low groundwater potential whereby, borehole yields are less than $1 \mathrm{~L} / \mathrm{s}$ (Chigor et al. 2013).

Sampling was carried out in September 2018 and nine sampling sites around the landfill facility were selected for soil collection including a reference sample (blank) (Fig. 1). At each site, samples were collected using a soil auger and emptied in polyethylene bags for further analysis. In the laboratory, soils were oven-dried and passed through a $2 \mathrm{~mm}$ sieve.

\section{ICP-MS Analysis}

Analysis of contaminants using ICP-MS began with the digestion of soil samples using the aqua regia EPA method 3015a (USEPA 1998). One gram of each soil sample was placed in a reaction vessel that contained $9 \mathrm{~mL}$ nitric acid (65\%), $2 \mathrm{~mL}$ hydrochloric acid (35\%) and $1 \mathrm{~mL}$ hydrogen peroxide (30\%). The reaction was allowed for $5 \mathrm{~min}$ before sealing the reaction vessels and placing it in a rotor for microwave digestion at $180^{\circ} \mathrm{C}$ for $5.5 \mathrm{~min}$. Samples were then held at the same temperature for 9.5 minutes and allowed to cool after digestion. Particulates in the digestant were removed by sedimentation before collecting it in plastic containers and labelling for ICP-MS analysis. Before this analysis, each sample was diluted 1000 times with $0.1 \%$ (v/v) nitric acid prepared using deionised water (milli-Q). ICP-MS Agilent 7500ce containing an octupole reaction system was used in this study that followed the EPA method 6020B (USEPA 2014). Analysis began with configuring the instrument computer using the manufacturer's directions and setting it up using appropriate operating parameters. The instrument was tuned and allowed to equilibrate for 30 minutes before analysis. This was followed by calibration using both internal and external standards containing rhenium and rhodium, respectively. A solution containing $1 \%$ nitric acid was used as the blank to flush the ICP-MS system until a steady-state signal was acquired. Samples beyond the linear analysis range were diluted before final analysis. A mixed solution standard was prepared in the blank solution and used to correct background interferences of the equipment from the solvent, air entrainment and plasma gases. Suitable isotopes were selected to eliminate possible isobaric spectral interferences due to ion species with many atoms before analysing the samples. The analysis was done in duplicates for $\mathrm{Cr}, \mathrm{Cu}, \mathrm{Ni}, \mathrm{Pb}$ and $\mathrm{Zn}$ and their final concentrations were determined using equation 1. 
Metal concentration $\left(\mathrm{mgkg}^{-1}\right)=\frac{\mathrm{ICP}-\mathrm{MS} \text { Reading } \times \text { Digestate volume } \times \text { Dilution Factor }}{\text { Weight of sample digested }}$

\section{XRF Analysis}

About $10 \mathrm{~g}$ of the dried soils were ground in a pulveriser to particles sizes of $75 \mu \mathrm{m}$ and below. The soils were emptied in crucibles and heated to $950^{\circ} \mathrm{C}$ for $2 \mathrm{~h}$ for loss on ignition (LOI) analysis to remove volatile organics. They were allowed to cool and transferred to aluminium containers for pressing in a semi-automated press. This study used the sequential XRF spectrometer (PW 2404, Phillips, Holland) that uses americium-241 and cadmium-109 isotopes for fluorescence excitation and has a detector made of silicon pin-diode. Before analysis, instrument performance was validated using a blank and two check samples that had high heavy metal levels before making adjustments on the zero level according to EPA method 6200 (USEPA 2016). The samples were placed on carriers that were previously cleaned using acetone and mounted on the equipment cassette for heavy metal analyses in triplicates through direct quantification.

\section{Calculation of Eco-Risk Indices}

Four eco-risk indices namely potential ecological risk index (PERI), cumulative risk index (CRI), toxic units (TU) and toxic risk index (TRI) were used to assess the ecological threat of trace metals to soils of the study area. PERI was calculated using equation 2 .

$$
\text { PERI }=\mathrm{T}_{\mathrm{r}} * \frac{\mathrm{C}_{\mathrm{obs}}}{\mathrm{C}_{\mathrm{norm}}}
$$

Where, $T_{r}$ is the toxic response coefficient of a particular metal, $\mathrm{C}_{\mathrm{obs}}$ is the measured concentration of given trace metal and $\mathrm{C}_{\text {norm }}$ is the geochemical background levels outlined by the Department of Environmental Affairs (DEA 2013). Toxic response coefficients are predefined values that account for sensitivity and toxic requirement (Pedersen et al. 1998). Elemental values of $T_{r}$ used to calculate PERI in this study are given in Table 5.

CRI was calculated using equation 3 .

$$
\mathrm{CRI}=\sum_{\mathrm{i}=1}^{\mathrm{n}} \text { PERI }
$$

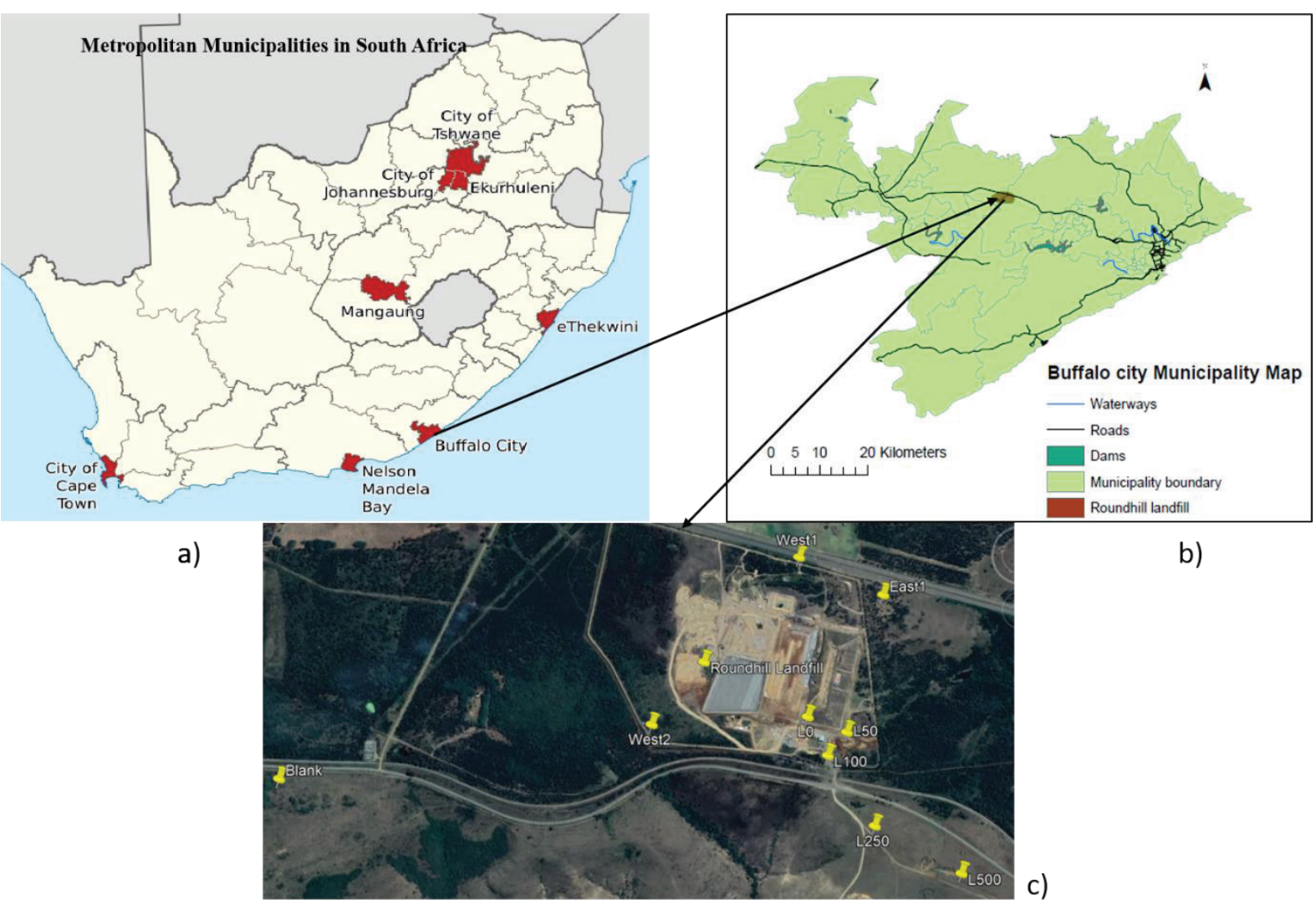

Fig. 1: Map of the study area and the distribution of sampling sites in relation to the landfill site. 
Where, $\mathrm{n}$ is the number of trace metals assayed and PERI is the potential ecological risk index of each metal.

TUs of individual metals at various sampling sites were calculated as relationships of observed metal concentration at each sampling site to predetermined probable effects level (PEL) as shown in equation 4.

$$
\mathrm{TU}=\frac{\mathrm{C}_{\mathrm{obs}}}{\mathrm{PEL}}
$$

Where, PEL is the probable effects level of individual metal, which is defined as the lower limit of chemical concentrations, which is affiliated to negative biological effects (Pedersen et al. 1998). PEL values of assayed elements used in this study were as shown in Table 5 and are derived from studies by Pedersen et al. (1998) and Zhu et al. (2018).

TRI assessed the integrated toxic risk using both PEL and threshold effect level (TEL) of heavy metals using equation 5.

$$
T R I=\sqrt{\left(C_{o b s /}{ }_{T E L}\right)^{2}}+\left(C_{o b s} / P E L\right)^{2} / 2
$$

Where, TEL is the threshold effects level, which is defined as the upper limit of soil chemical concentration that has no-effect data (Pedersen et al. 1998). TEL values used in this study were as documented by Zhu et al. (2018) and are presented in Table 5. Results of the above indices are categorised as given in Table 1.

\section{Geo-statistical Analysis}

The spatial analyst tool of ArcGis 10.3 was used in spatial interpolation of assayed pollutants and calculated indices of various sampling points. Inverse Distance Weighted (IDW) method, which takes a plug point as a core point of determining weighted averages for an entire area within a specified radius was used to represent pollution extent (Yan \& Li 2011). The method applied inverse proportioning between known concentrations and was represented using equation 6.

$$
\mathrm{Z}=\frac{\sum_{\mathrm{i}=1}^{\mathrm{n}} 1 /(\mathrm{Di}) \mathrm{p}}{\sum_{\mathrm{i}=1}^{\mathrm{n}} 1 /(\mathrm{Di}) \mathrm{p}} \mathrm{Z}_{\mathrm{i}}
$$

Where, $\mathrm{Z}=$ is the interpolated value, $\mathrm{Z}_{\mathrm{i}}=$ the sample value of $\mathrm{i}$ which $=1,2 \ldots \mathrm{n}, \mathrm{D}=$ distance and $\mathrm{p}=$ distance's power as described by Yan \& Li (2011).

\section{Statistical Analysis}

Descriptive statistics including the average (avg), standard deviation (SD), kurtosis and skewness of topsoils were applied to explain differences of ICP-MS and XRF elemental concentrations. The t-test assessed significant differences in the means of identified heavy metals for the two methods. The method has been used to compare differences in heavy metal concentrations obtained by XRF and ICP-MS successfully (Ahmed et al. 2012, Maliki et al. 2017). The Kolmogorov-Smirnov (K-S) test, which is an empirical distribution function (EDF) where theoretical and test distribution functions are compared was used in assessing normality or non-normality of the data (Ghasemi \& Zahediasi 2012). The method is preferred due to its high sensitivity compared to alternatives such as Shapiro-Wilk test, D'Agostino Pearson omnibus test, Anderson-Darling test and Jarque-Bera test (Oztuna et al. 2006). Mann Whitney U-test, a non-parametric was used to compare if sample means of the two methods were equal. The test was used to complement t-test by show-

Table 1: Criteria to classify calculated ecological risk indices.

\begin{tabular}{|llll|}
\hline Index Method & Values & Ecological risk level & Reference \\
\hline PERI & $\leq 40$ & Low & Sun et al. (2015) \\
& $40<$ PERI $\leq 80$ & Moderate & \\
& $80<$ PERI $\leq 160$ & High & \\
& $160<$ PERI $\leq 320$ & Very high & Zhu et al. (2018) \\
CRI & $>320$ & Extremely high & \\
& $<150$ & Low & Goderate \\
& $150-300$ & Considerable & \\
TU & $300-600$ & Disastrous & \\
& $\geq 600$ & Non-toxicity & \\
TRI & $<4$ & Acute toxicity & \\
& $>6$ & No toxic risk & \\
& $<5$ & Low risk & Moderate toxic risk \\
& $5 \leq \mathrm{TRI}<10$ & Considerable toxic risk & \\
& $10 \leq \mathrm{TRI}<15$ & Very high toxic risk & \\
\end{tabular}


ing differences in the spread for data that did not have normal distribution after the K-S test. To determine the correlation between heavy metal concentrations obtained by the two methods, linear regression analysis was applied. This analysis resulted in a linear model shown in Equation 7 that reduces the square difference between the regression line and the dependent variable (Kilbride et al. 2006).

$$
\mathrm{y}=\mathrm{mx}+\mathrm{c}+£
$$

Whereby, $\mathrm{y}$ is XRF concentration, $\mathrm{m}$ is the slope, $\mathrm{x}$ is the ICP-MS concentration, $c$ is the $y$-intercept of the regression line and $£$ is the residual.

Generally, $\geq 0.7$ value of determination coefficient $\left(R^{2}\right)$ represented the significant relationship of concentrations obtained from the two assay methods, while a value of 1.0 depicted an ideal case with no data scattering (Towett et al. 2013). These analyses were done using XLSTAT software at $\mathrm{p}<0.05$ significance level. Regressed data was subjected to a quality analysis using the USEPA (1998) criteria based on their determination coefficients and as shown in Table 2.

\section{RESULTS}

\section{Concentration of Contaminants}

Statistical comparisons of ICP-MS and XRF for the identified elements were as given in Table 3. Average concentrations of all elements obtained by ICP-MS were higher compared to those of XRF, which revealed under-estimations of the latter. A comparison of SD values of elemental concentrations obtained from the two techniques showed a similar trend of closeness in the variability of values except for $\mathrm{Pb}$. However, a comparison of SD values among identified elements showed a large spread where $\mathrm{Cr}$ and $\mathrm{Cu}$ had the highest and lowest values, respectively. Skewness, SD and kurtosis values for the two methods had the same tendency whereby values of $\mathrm{Cr}, \mathrm{Cu}, \mathrm{Ni}$ and $\mathrm{Zn}$ were nearly similar while those of $\mathrm{Pb}$ differed significantly.

\section{Comparison ICP-MS and XRF}

Results of K-S test, t-test and Mann Whitney U-test at P < 0.05 were as shown in Table 4 . K-S results showed normal distribution for all the elements except $\mathrm{Pb}$. The results of the Mann Whitney U-test showed a similar trend where $\mathrm{P}$ values of $\mathrm{Cr}, \mathrm{Cu}, \mathrm{Ni}$ and $\mathrm{Zn}$ were higher than 0.05 and corresponded to no differences in the two data sets, while $\mathrm{Pb}$ had significant differences. The means of the two data sets except $\mathrm{Pb}$ were found to be equal from the t-test.

To assess the data quality from the two methods, regression analysis was carried out and $\mathrm{R}^{2}$ values calculated as shown in Figs. 2 and 3. Determination coefficient values of $\mathrm{Cr}, \mathrm{Cu}$ and $\mathrm{Ni}$ were above 0.8 , which indicated that the results of the two methods were statistically similar for the concentrations of these elements. $\mathrm{Zn}$ had an $\mathrm{R}^{2}$ value of 0.7 and concentration levels obtained with the two methods were statistically different, but within the acceptable limit

Table 2: Criteria to categorise regression data quality based on $\mathrm{R}^{2}$ values (USEPA 1998).

\begin{tabular}{|llll|}
\hline Trace metal & Level of data quality & Statistical requirement & Inference \\
\hline $\mathrm{Cu}$ & Definitive & $\mathrm{R}^{2} 0.8$ & Relationship $\mathrm{y}=\mathrm{x}$ acceptable \\
$\mathrm{Cr}$ & & & \\
$\mathrm{Ni}$ & Quantitative Screening & $\mathrm{R}^{2}=0.7$ & Relationship $\mathrm{y}=\mathrm{mx}+\mathrm{c}$ acceptable \\
$\mathrm{Zn}$ & Qualitative screening & $\mathrm{R}^{2}<0.7$ & No relationship in data sets \\
$\mathrm{Pb}$ & & & \\
\hline
\end{tabular}

Table 3: A comparison of average concentrations, standard deviation, kurtosis and skewness values of top soils obtained by for ICP-MS and XRF.

\begin{tabular}{|c|c|c|c|c|c|}
\hline & $\mathrm{Cr}$ & $\mathrm{Cu}$ & $\mathrm{Ni}$ & $\mathrm{Pb}$ & $\mathrm{Zn}$ \\
\hline Avg-ICP $\left(\mathrm{mgkg}^{-1}\right)$ & 2197 & 246.67 & 535.56 & 104.96 & 244.89 \\
\hline $\operatorname{Avg}-X R F\left(\mathrm{mgkg}^{-1}\right)$ & 2044.56 & 239.56 & 497.33 & 104 & 175.56 \\
\hline SD-ICP & 2159.9 & 101.77 & 219.09 & 84.52 & 161.23 \\
\hline SD-XRF & 2147.98 & 107.92 & 205.79 & 172.03 & 134.45 \\
\hline Kurt-ICP & 8.5 & 3.38 & -0.75 & -0.43 & 7.06 \\
\hline Kurt-XRF & 8.56 & 3.3 & -0.62 & 1.4 & 7.25 \\
\hline Skew-ICP & 2.88 & 1.89 & 0.57 & 1.53 & 1.58 \\
\hline Skew-XRF & 2.9 & 1.64 & 0.73 & 0.52 & 1.6 \\
\hline
\end{tabular}



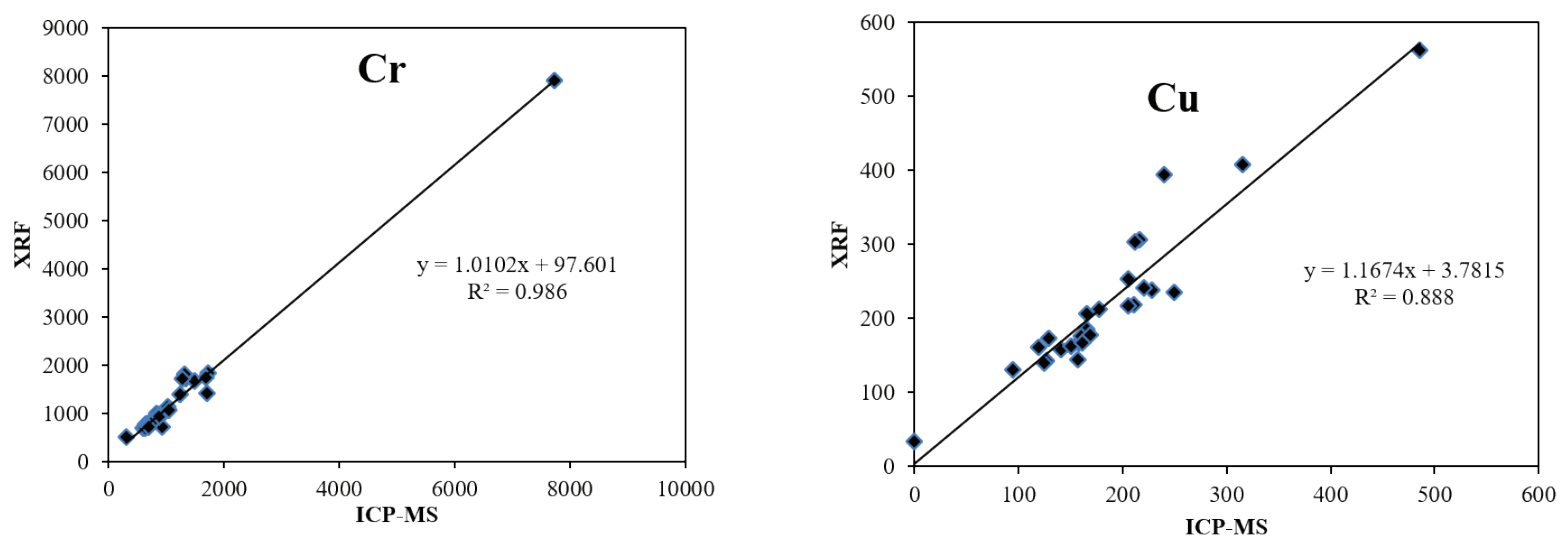

a)

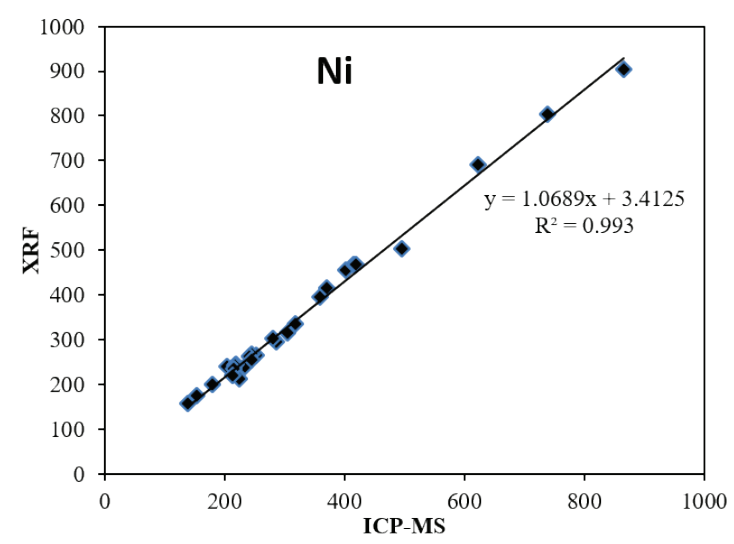

b)

c)

Fig. 2: Regression lines and equations for a) $\mathrm{Cr}, \mathrm{b}$ ) $\mathrm{Cu}$ and c) $\mathrm{Ni}$.

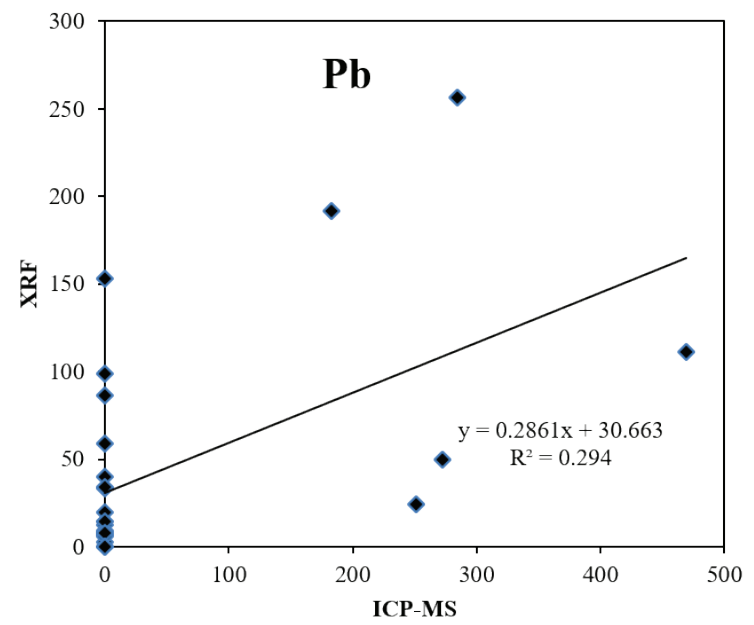

a)

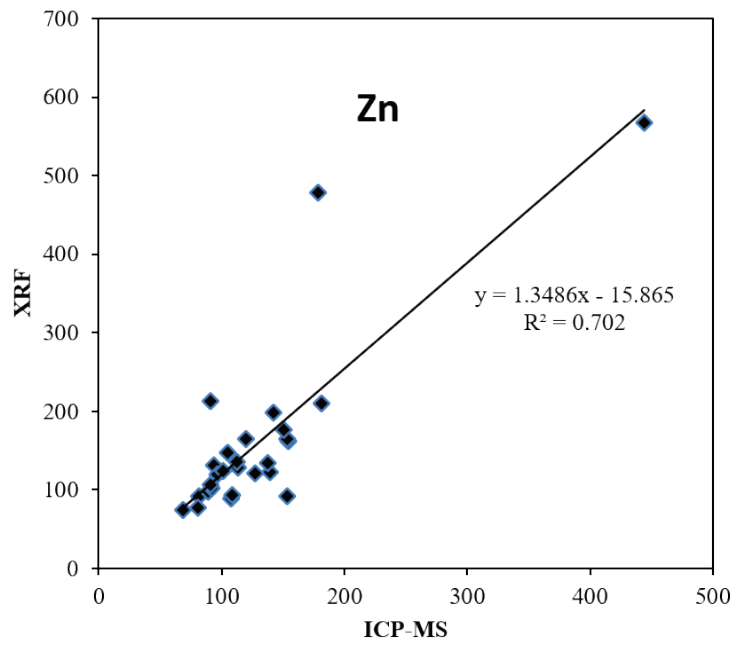

b)

Fig. 3: Regression lines, determination coefficients and regression equations for a) $\mathrm{Pb}$ and b) $\mathrm{Zn}$. 

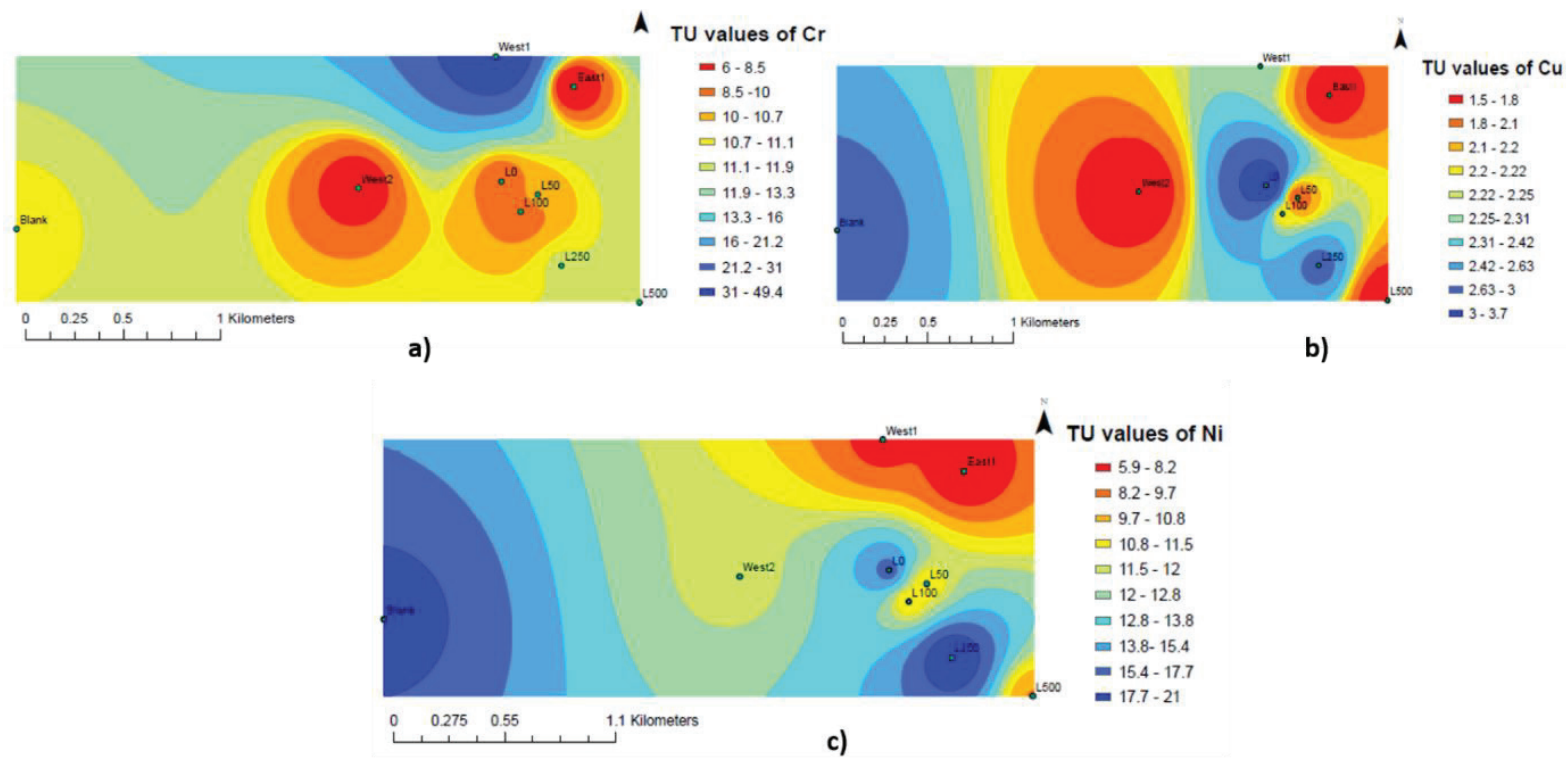

Fig. 4: Toxic Units (TU) of a) $\mathrm{Cr}, \mathrm{b}$ ) $\mathrm{Cu}$ and c) Ni.

Table 4: P values for K-S, Mann Whitney U-test and t-test of heavy metals concentrations at $95 \%$ significance level.

\begin{tabular}{|llll|}
\hline Variable & K-S test & $\begin{array}{l}\text { Mann Whitney } \\
\text { U-test }\end{array}$ & t-test \\
\hline $\mathrm{Cr}$ & 0.324 & 0.254 & 0.77 \\
$\mathrm{Cu}$ & 0.518 & 0.122 & 0.19 \\
$\mathrm{Ni}$ & 0.744 & 0.469 & 0.6 \\
$\mathrm{~Pb}$ & $<0.0001$ & 0.001 & 0.02 \\
$\mathrm{Zn}$ & 0.518 & 0.250 & 0.25 \\
\hline
\end{tabular}

$(\mathrm{y}=\mathrm{mx}+\mathrm{c}) . \mathrm{Pb}$ had $\mathrm{R}^{2}$ value $<0.7$ and its concentrations were statistically different. Regression lines of $\mathrm{Cr}, \mathrm{Cu}$ and Ni showed ideal linear regression models $(y=x)$ of concentrations obtained with the two methods. The regression line of $\mathrm{Zn}$ showed a significant and acceptable relationship of data obtained from the two methods, though with some deviations. The regression line of $\mathrm{Pb}$ had significant deviations in concentrations of the two methods.

\section{Ecological Risk Indices}

The concentrations of trace elements obtained by ICP-MS, which was a superior method compared to XRF were used to calculate ecological risk indices of study area soils. Potential ecological risk indices of trace elements at various sampling sites are given in Table 5. The values of PERI due to $\mathrm{Cr}$ were high in all sampling sites and depicted extremely high ecological risk except for the reference sample (Blank) that had a very high risk. PERI values of $\mathrm{Cu}$ ranged between 50 and 126, which was classified as moderate to high ecological risk while $\mathrm{Ni}, \mathrm{Pb}$ and $\mathrm{Zn}$ reported low ecological risk and had values $<40$ with a few exceptions. Cumulative Risk Index (CRI) was calculated as 430.28 , which correlated to the considerable ecological risk of the trace elements in sampled soils.

Spatial representation of various toxic units (TU) of assayed heavy metals at various sampling points was as shown in Fig. 4 and 5 (a-b). Toxic units of trace metals decreased in the order of $\mathrm{Cr}>\mathrm{Ni}>\mathrm{Cu}>\mathrm{Pb}>\mathrm{Zn}$. Acute risk due to $\mathrm{Cr}$ and Ni contamination was evident at all sampling points that had TUs values $\geq 6$. Non-toxicity by $\mathrm{Cu}, \mathrm{Pb}$ and $\mathrm{Zn}$, however, was reported in all sampling points whose TUs values were $<4$.

Toxic risk index (TRI) that considers PEL and TEL assessed the risk of trace metals in soils to the ecology of the area and results were spatially distributed as shown in Fig. 5c. TRI ranged between 13 and 113, which represented moderate to very high toxic risk. The highest levels of TRI were found in West 1 sampling site that had the highest concentrations of $\mathrm{Cr}$, which confirmed the high toxicity affiliated with the element.

\section{DISCUSSION}

Reproducibility results of XRF and ICP-MS analyses in this study were dependent on the element being quantified, although the former technique underestimated assayed trace elements concentrations. Underestimation was possibly due to differences in equipment sensitivity in the two methods. 

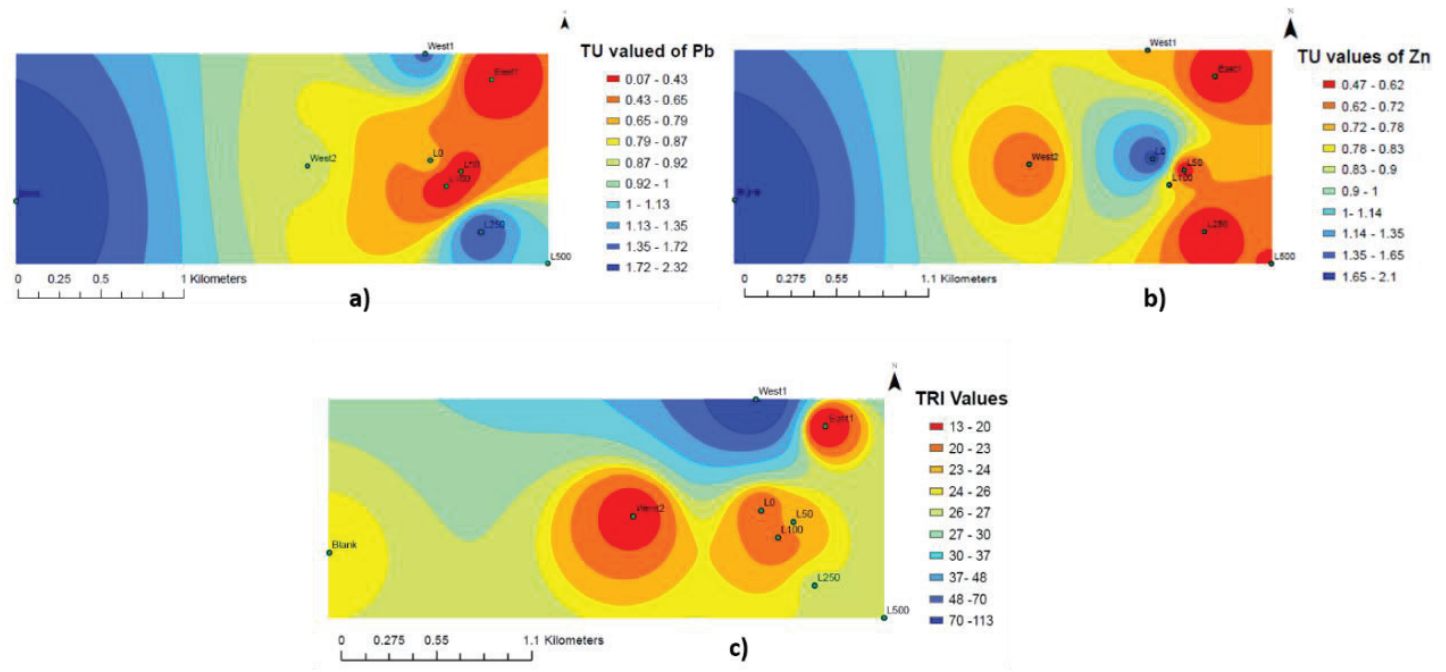

Fig. 5: Toxic units of a) $\mathrm{Pb}, \mathrm{b}$ ) $\mathrm{Zn}$ and Toxic Risk index (TRI) values at various sampling sites.

Table 5: Calculated potential ecological risk index (PERI) and cumulative risk index (CRI) values.

\begin{tabular}{|c|c|c|c|c|c|c|}
\hline & & PERI & & & & CRI \\
\hline & $\mathrm{Cr}$ & $\mathrm{Cu}$ & $\mathrm{Ni}$ & $\mathrm{Pb}$ & $\mathrm{Zn}$ & \\
\hline L0 & 528.31 & 95.94 & 17.65 & 64.00 & 2.36 & 430.28 \\
\hline L50 & 433.54 & 127.50 & 15.21 & 21.53 & 1.99 & \\
\hline L100 & 514.46 & 64.38 & 10.26 & 8.38 & 0.61 & \\
\hline $\mathrm{L} 250$ & 425.85 & 74.69 & 10.29 & 1.83 & 0.88 & \\
\hline L500 & 553.85 & 94.69 & 19.85 & 47.85 & 0.53 & \\
\hline West1 & 560.92 & 50.63 & 9.14 & 27.80 & 0.69 & \\
\hline West2 & 2430.46 & 79.38 & 6.90 & 38.25 & 0.83 & \\
\hline East1 & 349.23 & 50.94 & 11.05 & 24.63 & 0.73 & \\
\hline Blank & 287.38 & 55.63 & 5.58 & 1.90 & 0.56 & \\
\hline Normal concentrations & 6.5 & 16 & 91 & 20 & 240 & \\
\hline $\mathrm{T}_{\mathrm{r}}$ & 2 & 5 & 2 & 5 & 1 & \\
\hline PEL & 160 & 110 & 43 & 110 & 270 & \\
\hline TEL & 52 & 19 & 16 & 30 & 120 & \\
\hline
\end{tabular}

XRF has low sensitivity and high detection limits to trace metals in low concentrations while the sensitivity of ICPMS is high and enhanced by aqua regia digestion (Chen \& Ma 2001, Lin 2009). The low sensitivity in XRF explained the differences in skewness and kurtosis results of the two methods, particularly in $\mathrm{Pb}$. These findings disagreed with another comparative study that confirmed no differences in mean concentrations of $\mathrm{Pb}$ analysed by XRF and ICP-MS (Merkey et al. 2008). Parametric and non-parametric results of $\mathrm{Cr}, \mathrm{Cu}, \mathrm{Ni}$ and $\mathrm{Zn}$ ratified the effectiveness of the two methods and a similar trend was reported in a trace element analysis of soils obtained from Malaysian states (Ahmed et al. 2012) and sub-Saharan Africa (Towett et al. 2013).
Quantitative relationship of $\mathrm{Zn}$ and non-relationship of $\mathrm{Pb}$ concentrations from regression analysis could be attributable to underestimations of XRF, which is a function of its sensitivity at low concentrations and inter-element interferences (Towett et al. 2013). XRF's detection limits vary from sample to sample based on the anode's X-ray range, the sample composition, the mass of an element, counting time and tube voltage and some of these aspects could have compromised precise concentration measures in this study (Poto et al. 2015). Furthermore, XRF's detection limits differ based on the analyte being assayed, the strength of the excitation source, chemical and physical matrix effects (Makinen et al. 2005). Some of the aspects are difficult to standardize and could have led to the 
observed differences. Two studies that reported poor linearity of $\mathrm{Pb}$ in comparative XRF and ICP-MS analysis attributed the trend to these XRF equipment flaws (Potts et al. 1995, Kilbride et al. 2006). Under-estimation of concentrations by XRF was attributed to $\mathrm{K}$ and $\mathrm{L}$ line inter-elemental line interferences and overlaps, which reduce the equipment's detection intensity of the element (Stonach 2007). These interferences lead to overlapping spectrums that are predominant if assayed samples have arsenic and decrease fluorescence intensity causing underestimation of $\mathrm{Pb}$ (USEPA 1998).

ICP-MS was a more sensitive and superior contaminant analysis method over XRF in this study. Other publication agreed with this suggestion and highlighted the advantages of ICP-MS to be lower detection limits, reduced matric effects and no inter-elemental peak overlaps (Ahmed et al. 2012, Towett et al. 2013, McComb et al. 2014). The results differed from those of a study in Maddison, USA, that suggested that XRF had greater sensitivity of both major and trace elements (Herner et al. 2006).

Ecological risk indices showed different potency levels of the assayed elements. Cr had the highest PERI and TU values. The trend could arise due to anthropogenic enrichment of soils of the study area with landfill leachate from wood preservation, metallurgy, varnish, leather and electroplating wastes (Bini et al. 2008). In China, accumulation of $\mathrm{Cr}$ in landfill vicinity soils was attributed to the unscientific disposal of solid waste used in industrial processes such as electroplating and the construction industry (Cheng et al. 2014). High values of the indices for $\mathrm{Cr}$ compared to other trace elements even in the reference sample could point to its source as lithologic in addition to landfill leachate contamination. A study in urban soils of Beijing reported high PERI values of $\mathrm{Cr}$ compared to other elements and attributed it to natural origin from rocks in addition to the accumulation of untreated solid wastes in the area (Wang et al. 2012). CRI results of the current study that showed considerable eco-risk and differed from a study in soils of Yangcaogou region of China, which had CRI levels between 75.07 to 98.61 corresponding to the low ecological risk posed by trace metals (Jiang et al. 2014). However, a great contribution to the $\mathrm{CRI}$ was from $\mathrm{Cr}$, which suggested the high potency of the element as reported in another eco-assessment of soils from Caofeidian region of China (Zhu et al. 2018).

Accumulation of consumer and industrial by-products at the landfill could be attributable to acute toxicity by $\mathrm{Cr}$ and Ni-based on their TU values. Permenter et al. (2011) attributed the accumulation of $\mathrm{Cr}$ and $\mathrm{Ni}$ in soils to disposal of stainless steel, chrome pigments, plating and alloy-containing solid waste. This dominance of $\mathrm{Cr}$ and $\mathrm{Ni}$ toxicity in this study agreed with an eco-risk evaluation study of soils from Bangladesh, where all TU values of sampling sites were $>6$ (Islam et al. 2015). Soils of the area had moderate to very high toxic risk based on TRI values. The results of this index differed from a related study of Chinese soils that reported a low-risk TRI range of 3.08-8.25 (Zhu et al. 2018).

\section{CONCLUSIONS}

Concentrations of $\mathrm{Cr}, \mathrm{Cu}, \mathrm{Ni}, \mathrm{Pb}$ and $\mathrm{Zn}$ in this study were assayed using ICP-MS and XRF and the results of the former were used to calculate eco-risk indices. $\mathrm{Cr}$ had the highest concentration compared to other trace elements. Concentrations determined using XRF for all elements were under-estimated in comparison with ICP-MS, which could be attributed to the low sensitivity, high detection limits and inter-elemental interferences during XRF analysis. These underestimations were reflected in the regression analysis that showed deviations and qualitative relationship in XRFICPMS datasets of $\mathrm{Pb}$ and $\mathrm{Zn}$, respectively, although $\mathrm{Cr}$, $\mathrm{Cu}$ and $\mathrm{Ni}$ had ideal relationships. Eco-risk indices showed that $\mathrm{Cr}$ had the highest potential ecological risk based on the PERI and TU values and compared to other elements. This trend could arise from landfill leachate generated from wood preservation, metallurgy, varnish, leather and electroplating wastes. Lithologic sources of trace elements were suggested based on the high $\mathrm{TU}$ values of $\mathrm{Cu}, \mathrm{Ni}, \mathrm{Pb}$ and $\mathrm{Zn}$ in the reference sampling site. Moderate to high toxic risk was deduced from TRI values at various sampling sites. Calculated risk indices and their spatial representation revealed ecological risk from assayed trace elements in soils of Roundhill landfill vicinity, which was possibly linked to leachate pollution.

\section{REFERENCES}

Ahmed, A., Abdullah, P., Khalik Wood, A., Hamza, S. and Othman, M. 2012. Determination of some trace metals in marine sediments using ICP-MS and XRF: A comparative study. Oriental Journal of Chemistry, 29: 1-9.

Bini, C., Maleci, L. and Romanin, A. 2008. The chromium issue in soils of the leather tannery district in Italy. Journal of Geochemical Exploration, 96(2-3): 194-202.

Chen, M. and Ma, L. 2001. Comparison of three aqua regia digestion methods for twenty Florida soils. Soil Science Society American Journal, 651: 491-499.

Cheng, H., Zhou, T., Li, Q., Lu, L. and Lin, C. 2014. Anthropogenic chromium emissions in China from 1990-2009. PLoS One, 9(2): e87753.

Chigor V., Sibanda, T. and Okoh. A. 2013. Studies on the bacteriological qualities of the Buffalo River and three water dams along its course in the Eastern Cape province of South Africa. Environmental Science and Pollution Resources 20: 4125-4136.

Department of Environmental Affairs (DEA) 2013. National Environmental Management, Waste Act, 2008. National norms and standards for the remediation of contaminated land and soil quality in the Republic of South Africa. Government Gazette, No. 36447.

Dookhi, N., Jewaskiewitz, S. and Jewaskiewitz, B. 2015. East London regional (Roundhill) waste disposal site-wasting no time on the road 
to compliance. Journal of the South African Institution of Civil Engineering, 23(9): 35-42.

Gao, L., Wang, Z., Li, S. and Chen, J. 2018. Bioavailability and toxicity of trace metals $(\mathrm{Cd}, \mathrm{Cr}, \mathrm{Cu}, \mathrm{Ni}$, and $\mathrm{Zn})$ in sediment cores from the Shima River, South China. Chemosphere, 192: 31-42.

Ghasemi, A. and Zahediasi, S. 2012. Normality tests for statistical analysis: A guide for non-statisticians. International Journal of Endocrinology and Metabolism, 10: 486-489.

Hakanson, L. 1980. An ecological risk index for aquatic pollution control: A sedimentological approach. Water Research, 14(8): 975-1001.

Herner, J., Green, P. and Kleeman, M. 2006. Measuring the trace elemental composition of size-resolved airborne particles. Environmental Science and Technology, 40: 1925-1933.

Islam, S., Ahmed, K., Al-Mamun, H. and Masunaga, S. 2015. Potential ecological risk of hazardous elements in different land-use urban soils of Bangladesh. Science of the Total Environment, 512-513: 94-102.

Jiang, X., Lu, W., Zhao, H., Yang, Q. and Yang, Z. 2014. Potential ecological risk assessment and prediction of soil heavy metal pollution around coal gangue dump. Natural Hazards and Earth System Sciences, 14: 1599-1610

Kilbride, C., Poole, J. and Hutchings, T.R. 2006. A comparison of $\mathrm{Cu}, \mathrm{Pb}$, $\mathrm{As}, \mathrm{Cd}, \mathrm{Zn}, \mathrm{Fe}, \mathrm{Ni}$ and $\mathrm{Mn}$ determined by acid extraction/ICP-OES and ex situ field portable X-ray fluorescence analyses. Environmental Pollution, 143: 16-23.

Lin, J. 2009. Performance of the thermo scientific niton XRF analyzer: the effects of particle size, length of analysis, water, organic matter and soil chemistry. Available Online: http://nature.berkeley.edu/classes/ es196/projects/2009finalLinJ_2009.pdf [Accessed on 17 March 2018]

Makinen, E., Korhonen, M., Viskari, E., Haapamaki, S., Jarvinen M. and Lu, L. 2005. Comparison of XRF and FAAS methods in analysing CCA contaminated soils. Water, Air and Soil Pollution, 171: 95-110.

Maliki, A., Al-Lami, A., Hussain, H., and Al-Ansari, N. 2017. Comparison between inductively coupled plasma and X-ray fluorescence performance for $\mathrm{Pb}$ analysis in environmental soil samples. Environment and Earth Science, 76: 433.

Marcos, D., Jason, P., Humberto, G., Alba, C., Gustavo, C., Alfredo, C., Alberto, D. and Jorge, G. 2011. Comparison of ICP-OES and XRF performance of $\mathrm{Pb}$ and $\mathrm{As}$ analysis in environmental soil samples from Chihuahua city, Mexico. Physical Review Research International, 1: 29-44.

Mccomb, J., Rogers, C., Han, F. and Tchounwou, P. 2014. Rapid screening of heavy metals and trace elements in environmental samples using portable X-ray fluorescence spectrometer, a comparative study. Water, Air and Soil Pollution, 225: 2169.

Merkey, A., Clark, C., Succop, P. and Roda, S. 2008. Determination of feasibility of using a portable X-ray fluorescence (XRF) analyser in the field for measurement of lead content of sieved soil. Journal of Environmental Health, 70: 24-29.

Oztuna, D., Elhan, A.H. and Tuccar, E. 2006. Investigation of four different normality tests in terms of type 1 error rate and power under different distributions. Turkish Journal of Medical Sciences, 36: 171-176.

Pedersen, F., Bjornestad, E., Andersen, H., Kjolholt, J. and Poll, C. 1998.
Characterisation of sediments from Copenhagen Harbour by use of biotests. Water Science and Technology, 37 (6-7): 233-240.

Permenter, M., Lewis, J. and Jackson, D. (2011). Exposure to nickel, chromium, or cadmium causes distinct changes in the gene expression patterns of a rat liver derived cell line. PLoS ONE 6(11): e27730.

Poggio, L. and Vrscaj, B. 2009. A GIS-based human health risk assessment for urban green space planning an example from Grugliasco (Italy). The Science of the Total Environment, 407: e5961-e5970.

Poto, L., Gabrieli, J., Crowhurst, S. and Agostinelli, C. 2015. Cross calibration between XRF and ICP-MS for high spatial resolution analysis of ombrotrophic peat cores for palaeoclimatic studies. Analytical and Bioanalytical Chemistry, 407: 379-384.

Potts, P.J., Webb, P.C., Williams-Thorpe, O. and Kilworth, R. 1995. Analysis of silicate rocks using field portable X-ray Fluorescence instrumentation incorporating a mercury(II) iodide detector: A preliminary assessment of analytical performance. The Analyst, 120: 1273-1278.

Radu, T. and Diamond, D. 2009. Comparison of soil pollution concentrations determined using AAS and portable XRF techniques. Journal of Hazardous Materials, 171: 1168-1171.

Shokr, M., El-Baroudy, A., Fullen, M., El-Beshbeshy, T., Ramadan, A., Halim, A., Guerra, A. and Jorge, M. 2016. Spatial distribution of heavy metals in the middle Nile delta of Egypt. International Soil and Water Conservation Research, 4(4): 293-303.

Stonach, H. 2007. S2 PICOFOX total reflection X-ray fluorescence spectroscopy-working principles. Lab Report. Bruker AXS microanalysis GmbH [Report No. XRF 426].

Sun, Z., Mou, X., Tong, C., Wang, C., Xie, Z., Song, H., Sun, W. and Lv, Y. 2015. Spatial variations and bioaccumulation of heavy metals in intertidal zone of the Yellow River estuary, China. Catena, 126: 43-52.

Towett, E., Shepherd, K., and Cadisch, G. 2013. Quantification of total element concentrations in soils using total X-ray fluorescence spectroscopy (TXRF). Science of Total Environment, 463(4): 374-8.

United States Environmental Protection Agency (USEPA) 1998. Method 3015a, Microwave assisted acid digestion of aqueous samples and extracts. Washington DC: US Environmental Protection Agency.

USEPA 2014. Method 6020B (SW-846): Inductively coupled plasma-mass spectrometry. Revision 2, Washington, DC: US Environmental Protection Agency.

USEPA 2016. SW-846 test method 6200: Field portable X-ray fluorescence spectrometry for the determination of elemental concentrations in soils and sediments. Washington, DC: US Environmental Protection Agency.

Wang, M., Bai, Y., Chen, W., Markert, B., Peng, C. and Ouyang, Z. 2012. A GIS technology based potential eco-risk assessment of metals in urban soils in Beijing, China. Environmental Pollution, 161: 235-242.

Yan, B. and Li, Y. 2011. GIS-based study on spatial variability of groundwater quality in Xianyan city. 2011 International Symposium on Water Resource and Environmental Protection. 20-22 May 2011, IEEE, Xi' an, China.

Zhu, H., Bing, H., Yi, H., Wu, Y. and Sun, Z. 2018. Spatial distribution and contamination assessment of heavy metals in surface sediments of the Caofeidian adjacent sea after the land reclamation, Bohai City. Journal of Chemistry, 1-13. 